\title{
PENGARUH PEMBERIAN KOMPOS LIMBAH PERTANIAN TERHADAP PERTUMBUHAN DAN SERAPAN NITROGEN TANAMAN JAGUNG (Zea mays L.)
}

\author{
Roudhotul Chasanah ${ }^{1^{*}}$, Anis Sholihah ${ }^{2}$, Agus Sugianto ${ }^{2}$ \\ ${ }^{1}$ Mahasiswa S1 Agroteknologi Fakultas Pertanian, Universitas Islam Malang \\ ${ }^{2}$ Dosen Program Studi Agroteknologi, Fakultas Pertanian Universitas Islam Malang \\ Jl. MT. Haryono No. 193 Malang 65144, Jawa Timur, Indonesia \\ Korespondensi: Roudhotul.chasanah18@gmail.com
}

\begin{abstract}
Abstrak
Jagung Merupakan salah satu tanaman serealia yang banyak dibudidayakan yang berperan penting dalam mencukupi kebutuhan pangan, sehingga produksi tanaman jagung semakin tahun semakin meningkat. Untuk meningkatkan produksi tanaman jagung biasanya para petani menggunakan pupuk anorganik, tetapi dalam jangka panjang penggunaaan pupuk anorganik ini tidak efektif terutama dalam kesuburan tanah. Penelitian ini berjuan untuk mengetahui pengaruh pemberian kompos dan dosis yang berbeda terhadap pertumbuhandan serapan $\mathrm{N}$ tanaman jagung serta untuk mendapatkan dosis optimum masing - masing kompos untuk meningkatkan serapan $\mathrm{N}$ tanaman jagung. Penelitian ini bertempatkan di rumah plastik desa Losari, Singosari, Malang dengan rancangan percobaan RAK Faktorial dengan Kontrol, dimana ada dua faktor, masing - masing faktor terdapat 4 taraf yaitu faktor pertama : P1= Kompos jerami, $\mathrm{P} 2=$ Kompos Kedelai, $\mathrm{P} 3=$ Kompos kacang tanah, dan $\mathrm{P} 4=$ Kompos tebu, sendangkan faktor kedua D1 = 5 ton/ha, D2 = 10 ton/ha, D3 = 15 ton/ha, dan D1 = 20 ton/ha. Terdapat 16 kombinasi ditambah kontrol $=17$ perlakuan, $17 \times 3$ ulangan $\times 3$ sampel $=153$ unit percobaan. Analisis data menggunakan Anova 5\% jika nyata diuji lanjut menggunakan BNJ 5\% dan untuk menentukan dosis optimum dilakukan analisis regresi. Hasil penelitian menunjukkan bahwa secara terpisah perlakuan P3 memberikan hasil terbaik pada paramater tinggi tanaman, diameter batang, jumlah daun dan luas daun. Perlakuan P3 memberikan hasil dosis optimum terbaik pada serapan $\mathrm{N}$-total dengan nilai determinasi sebesar $94,46 \%$ diperoleh dosis optimum 11,44 ton/ha.
\end{abstract}

Kata Kunci : Jagung, kompos, dosis, jerami padi, kedelai, kacang tanah, dan tebu

\begin{abstract}
Abstrak
Corn is one of the most cultivated cereals that plays an important role in meeting food needs so that the production of corn plants is increasing every year. To increase the production of corn, farmers usually use inorganic fertilizer, but in the long run, the use of inorganic fertilizer is not effective, especially in soil fertility. This study aims to determine the effect of different compost and dosages on growth and $\mathrm{N}$ uptake of corn plants and to obtain the optimum dosage of each compost to increase $\mathrm{N}$ uptake of corn plants. This research was placed in a plastic house in Losari village, Singosari, Malang with a factorial RAK experimental design with Control, where there were two factors, each factor there were four levels, namely the first factor: P1 = straw compost, $\mathrm{P} 2$ = soybean compost, $\mathrm{P} 3$ = bean compost soil, and $\mathrm{P} 4=$ sugarcane compost, whereas the second factor is D1 = 5 tons / ha, D2 $=10$ tons / ha, D3 = 15 tons/ha, and D1 $=20$ tons / ha. There are 16 combinations plus control $=17$ treatments, $17 \times 3$ replications $\times 3$ samples $=153$ experimental units. Data analysis used $5 \%$ Anova if it was tested further using a $5 \% \mathrm{BNJ}$ and to determine the optimum dose regression analysis was performed. The results showed that separately the P3 treatment gave the best results on parameters of plant height, stem diameter, number of leaves, and leaf area. P3 treatment gives the best optimum dosage results on $\mathrm{N}$-total uptake with a determination value of $94.46 \%$; the optimum dose obtained is 11.44 tons/ha.
\end{abstract}

Keywords : Corn, compost, dosage, rice straw, soybean, bean, and sugarecane

\section{Pendahuluan}


Jagung Merupakan salah satu tanaman serealia yang banyak dibudidayakan yang berperan penting dalam mencukupi kebutuhan pangan, sehingga produksi tanaman jagung semakin tahun semakin meningkat. Menurut Badan Pusat Statistik (2018) bahwa produksi jagung Indonesia sejak 1980-2017 menunjukkan tren kenaikan, ini sejalan dengan meningkatnya luas lahan panen dalam periode yang sama. Peningkatan produksi tanaman jagung dapat tercapai apabila semua komponen produksi terpenuhi yang salah satunya adalah kesuburan tanah. Kesuburan tanah berperan penting terhadap pertumbuhan dan produksi tanaman jagung, para petani di Indonesia dalam meningkatkan kesuburan tanah salah satunya menggunakan pupuk anorganik, karena diyakini dapat meningkatkan produksi jagung. Namun, penggunaan pupuk anorganik yang relatif tinggi dan terus-menerus menjadi penyebab menurunnya kesuburan tanah bila tidak diimbangi dengan penggunaan pupuk organik dan pupuk hayati. Seperti yang dikemukakan oleh Notohadiprawiro (2006), bahwa penggunnaan pupuk anorganik yang terus menerus dapat mengakibatkan pengerasan pada tanah. Hal tersebut dikarenakan sifat bahan kimia yang terkandung dalam pupuk anorganik tidak dapat terurai. Semakin keras lahan pertanian maka dapat berakibat pada fungsi akar, dimana terjadi penurunan karena proses pernapasan dan penyerapan unsur hara di dalam tanah akan terganggu yang berakibat dapat menurunkan pertumbuhan dan produktivitas tanaman sehingga, keadaan ini akan menurunkan produktivitas lahan. Dalam upaya meningkatkan produktivitas lahan secara berkelanjutan diperlukan terobosan yang mengarah pada efisiensi usahatani dengan memanfaatkan sumberdaya lokal dengan memanfaatkan limbah-limbah pertanian yang mudah di dapat petani di sekitar daerah mereka (Arafah, 2003). Tujuan Penelitian ini adalah untuk mengetahui pengaruh pemberian kompos dari limbah pertanian organik dengan dosis yang berbeda serta berapa dosis dosis optimum kompos yang dapat meningkatkan pertumbuhan tanaman jagung.

\section{Bahan dan Metode}

Penelitian ini bertempatkan di rumah plastik desa Losari, Kecamatan Singosari Kabupaten Malang Jawa Timur dan Laboratorium Terpadu Fakultas Pertanian Universitas Islam Malang. Analisis Dasar Tanah dan Kompos Bertempatkan di Laboratorium Kimia dan Biologi Tanah, Jurusan Tanah Fakultas Pertanian Universitas Islam Malang. Serta Analisis Serapan N dilakukan di Laboratorium Tanah dan Air UPT PATPH ( Pengembangan Agribisnis Tanaman Pangan dan Hortikultura) Bedali, Lawang Jawa Timur. 
Penelitian ini menggunakan rancangan acak kelompok faktorial dengan kontrol, yang terdiri dari dua faktor masing-masing faktor terdiri 4 taraf.

Faktor Pertama terdiri dari 4 level $(\mathrm{P} 1=$ Kompos Jerami, P2 $=$ Kompos Kedelai, P3= Kompos Kacang Tanah P4 = Kompos Tebu), sedangkan Faktor Kedua terdiri dari 4 level yakni D1 = 5 ton/ha, D2 = 10 ton/ha, D3 = 15 ton/ha, D4 = 20 ton/ha)

Dari dua faktor didapatkan 16 kombinasi perlakuan ditambah kontrol menjadi 17 perlakuan, dari 17 perlakuan masing - masing ada 3 sampel dan diulang 3 kali. Sehingga $17 \times 3 \times 3=153$ unit percobaan. Pengamatan dilakukan dengan interval 1 minggu sekali hingga umur 8 MST meliputi Variabel Pertumbuhan dan Variabel Kualitas, adapun variabel pertumbuhan meliputi : tinggi tanaman, diameter batang, jumlah daun dan luas daun sedangkan variabel kualitas terdiri dari serapan $\mathrm{N}$ tajuk dan akar, Serapan $\mathrm{N}$-total, \% $\mathrm{N}$ recovery, dan Efisisensi $\mathrm{N}$.

Hasil pengamatan kemudian dianalisis menggunakan uji $F$ 5\%, jika terdapat pengaruh yang nyata maka dilakukan uji lanjut BNJ dengan taraf $5 \%$. Serta Uji analisis Regresi untuk menentukan tingkat dosis optimum dalam aplikasi pemberian kompos limbah pertanian.

Penelitian di mulai dari persiapan bahan yaitu tanah dan kompos limbah pertanian. untuk mendapatkan kompos limbah pertanian dilakukan proses pengomposan dengan cara menambahkan limbah pertanian (jerami padi, kedelai, kacang tanah dan tebu) yang sebelumnya sudah kering dan digiling halus, ditambahkan air yang sudah dicampur dengan $10 \mathrm{ml}$ EM4 + 15 gram NPK. Selama proses ini dilakukan dengan pengecekan suhu, apabila suhu naik diatas $50^{\circ} \mathrm{C}$ maka kompos diangin - anginkan agar suhu dan pH kembali normal dan diaduk - aduk secara merata agar memperoleh kematangan kompos yang seragam sekitar 21 hari proses pengomposan. Selanjutnya aplikasi dalam percobaan pot yang terdiri dari campuran $10 \mathrm{~kg}$ + bahan organik + kompos sesuai perlakuan. Media tanah dalam pot diberi pupuk dasar urea, SP-36, dan $\mathrm{KCl}$ dengan pemberian secara bertahap. Pot ditanami 5 biji jagung, setelah 1 minggu ditinggalkan 1 tanaman yang pertumbuhannya paling bagus, kemudian ditempatkan di rumah kaca dengan penempatan sesuia denah rancangan percobaan yang digunakan. Variabel pengamatan terdiri dari tinggi tanaman, diameter batang, jumlah daun, luas daun dan serapan $\mathrm{N}$-total tanaman. Serapan $\mathrm{N}$ tanaman jagung (\%) meliputi akar dan tajuk tadaun tanaman dilakukan ketika jagung berumur 8 minggu dengan mengoven akar dan tajuk daun pada suhu $60^{\circ} \mathrm{C}$ selama 48 jam selanjutnya dianalisis kandungan $\mathrm{N}$ pada tajuk dan akar dengan metode Kjeldahl. Kemudian dihitung dengan rumus : 


$$
\begin{array}{ll}
\text { Serapan N Tajuk Daun } & =\text { Kandungan N \% X BK Tanaman (gram) } \\
\text { Serapan N Akar } & =\text { Kandungan N \% X BK Akar (gram) } \\
\text { N-total } & =\text { Serapan N Tajuk Daun + Serapan N Akar }
\end{array}
$$

Keterangan : $\mathrm{BK}=$ Bobot Kering

\section{Hasil dan Pembahasan}

\section{Pertumbuhan Tanaman Jagung}

Hasil Analisis ragam menunjukkan bahwa pemberian kompos dengan dosis yang berbeda pada umur 1-7 MST tidak ada interaksi yang nyata tetapi secara terpisah terdapat pengaruh yang nyata pada parameter pengamatan

Hasil analisis ragam menunjukkan perlakuan penambahan kompos jerami, kedelai, kacang tanah dan tebu pada media tanah dengan perbedaan dosis $(5,10,15$

\begin{tabular}{|c|c|c|c|c|c|c|c|}
\hline \multirow{2}{*}{ Perlakuan } & \multicolumn{7}{|c|}{ Rerata Tinggi Tanaman (cm) Pada Umur Pengamatan (MST) } \\
\hline & $1 \mathrm{MST}$ & 2 MST & 3 MST & 4 MST & 5 MST & 6 MST & $7 \mathrm{MST}$ \\
\hline$P_{1}$ & 16,13 & 32,09 & 51,29 a & 75,24722 & $\begin{array}{c}110,88 \\
a\end{array}$ & $\begin{array}{c}147,26 \\
a\end{array}$ & $\begin{array}{c}200,09 \\
a\end{array}$ \\
\hline $\mathrm{P}_{2}$ & 15,34 & 32,21 & 49,68 a & 74,83611 & $\begin{array}{c}103,68 \\
a\end{array}$ & $\begin{array}{c}160,09 \\
a\end{array}$ & $\begin{array}{c}199,33 \\
a\end{array}$ \\
\hline $\mathrm{P}_{3}$ & 17,61 & 35,28 & 57,36 a & 83,95556 & $\begin{array}{c}127,98 \\
a\end{array}$ & $\begin{array}{c}181,46 \\
a\end{array}$ & $\begin{array}{c}225,99 \\
a\end{array}$ \\
\hline $\mathrm{P}_{4}$ & 16,31 & 34,14 & $53,95 \mathrm{a}$ & 81,79167 & $\begin{array}{c}125,01 \\
a \\
\end{array}$ & $\begin{array}{c}177,47 \\
a \\
\end{array}$ & $\begin{array}{c}214,49 \\
a \\
\end{array}$ \\
\hline BNJ 5\% & TN & TN & 18,13 & TN & 49,04 & 53,12 & 47,27 \\
\hline $\mathrm{D}_{1}$ & 16,58 & 35,08 & 55,61 & 82,25 & 123,83 & 171,65 & 210,78 \\
\hline$D_{2}$ & 16,01 & 33,07 & 52,25 & 76,56 & 114,71 & 162,83 & 200,72 \\
\hline $\mathrm{D}_{3}$ & 16,92 & 33,66 & 53,01 & 79,90 & 116,19 & 168,54 & 212,68 \\
\hline $\mathrm{D}_{4}$ & 15,88 & 31,91 & 51,41 & 77,11 & 112,82 & 163,26 & 215,74 \\
\hline BNJ 5\% & TN & TN & TN & TN & TN & TN & TN \\
\hline
\end{tabular}
dan 20 ton/ha) memberikan pengaruh yang nyata pada uji $F$ 5\%. Hasil uji BNJ 5\% terhadap rata-rata panjang tanaman pada disajikan pada Tabel 1 dan 2 Tabel 1. Rata-rata Tinggi tanaman

Tabel 2. Rata - rata tinggi tanaman jagung $(\mathrm{cm})$ terhadap pemberian kompos dan dosis yang berbeda

\begin{tabular}{c|c}
\hline \multirow{2}{*}{ Perlakuan } & Rata-rata Tinggi Tanaman Jagung Pada Umur Pengamatan \\
\cline { 2 - 2 } & $\mathbf{8} \mathbf{~ M S T}$ \\
\hline Kontrol & $214,44 \mathrm{a}$ \\
$\mathrm{P}_{1} \mathrm{D}_{1}$ & $254,33 \mathrm{bcd}$ \\
$\mathrm{P}_{1} \mathrm{D}_{2}$ & $248,67 \mathrm{abcd}$ \\
$\mathrm{P}_{1} \mathrm{D}_{3}$ & $242,36 \mathrm{abc}$ \\
$\mathrm{P}_{1} \mathrm{D}_{4}$ & $230,72 \mathrm{abc}$
\end{tabular}




\begin{tabular}{c|c}
$P_{1} D_{1}$ & $251,00 \mathrm{abcd}$ \\
$P_{1} D_{2}$ & $217,83 \mathrm{ab}$ \\
$P_{1} D_{3}$ & $214,91 \mathrm{a}$ \\
$P_{1} D_{4}$ & $241,33 \mathrm{abc}$ \\
$P_{3} D_{1}$ & $235,56 \mathrm{abc}$ \\
$P_{3} D_{2}$ & $286,00 \mathrm{~d}$ \\
$P_{3} D_{3}$ & $259,22 \mathrm{bcd}$ \\
$P_{3} D_{4}$ & 263,44 bcd \\
$P_{4} D_{1}$ & 266,00 bcd \\
$P_{4} D_{2}$ & 243,89 abcd \\
$P_{4} D_{3}$ & $269,67 \mathrm{~cd}$ \\
$P_{4} D_{4}$ & 232,22 abc \\
\hline BNJ 5\% & 37,73 \\
\hline Keterangan: Angka yang didampingi dengan notasi yang sama pada kolom yang sama menunjukkan hasil tidak \\
berbeda nyata dengan uji BNJ 5\%. TN = Tidak Nyata. Mst = Minggu Setelah Tanam. $P 1=$ Brangkasan \\
jerami padi, P2= Brangkasan kedelai, P3= Brangkasan kacang tanah, P4= Brangkasan tebu.
\end{tabular}

Pada Tabel 2. menunjukkan pada umur 8 MST tinggi tanaman tertinggi pada perlakuan $\mathrm{P}_{3} \mathrm{D}_{2}$ (kompos kacang tanah dengan dosis 10 ton/ha) sebesar $(286,00 \mathrm{~cm}$ ) berbeda nyata dengan perlakuan Kontrol, $P_{1} D_{3}, P_{1} D_{4}, P_{2} D_{2}, P_{2} D_{3}, P_{2} D_{4}, P_{3} D_{1}$, dan $P_{4} D_{4}$. Dan tidak berbeda nyata dengan perlakuan $P_{1} D_{1}, P_{1} D_{2}, P_{1} D_{4}, P_{2} D_{1}, P_{3} D_{3}, P_{3} D_{4}, P_{1} D_{4}$, $\mathrm{P}_{2} \mathrm{D}_{4}$, dan $\mathrm{P}_{3} \mathrm{D}_{4}$

\section{Diameter Batang}

Hasil analisis ragam menunjukkan perlakuan penambahan kompos jerami, kedelai, kacang tanah dan tebu pada media tanah berpengaruh nyata terhadap terhadap diameter batang selama pengamatan. Hasil uji BNJ 5\% terhadap rata-rata diameter batang dapat disajikan pada Tabel 5, 6, dan 7.

Tabel 5. Rata - Rata Diameter Batang Tanaman Jagung ( $\mathrm{mm}$ ) Terhadap Pemberian Kompos Dan Dosis Yang Berbeda

\begin{tabular}{l|c}
\hline Perlakuan & Rata-rata \\
\hline Kontrol & $9,20 \mathrm{ab}$ \\
$\mathrm{P}_{1} \mathrm{D}_{1}$ & $12,66 \mathrm{abcde}$ \\
$\mathrm{P}_{1} \mathrm{D}_{2}$ & $9,42 \mathrm{abc}$ \\
$\mathrm{P}_{1} \mathrm{D}_{3}$ & $9,73 \mathrm{abc}$ \\
$\mathrm{P}_{1} \mathrm{D}_{4}$ & $9,90 \mathrm{abcd}$ \\
$\mathrm{P}_{2} \mathrm{D}_{1}$ & $12,67 \mathrm{abcde}$ \\
$\mathrm{P}_{2} \mathrm{D}_{2}$ & $8,94 \mathrm{a}$ \\
$\mathrm{P}_{2} \mathrm{D}_{3}$ & $9,08 \mathrm{a}$ \\
$\mathrm{P}_{2} \mathrm{D}_{4}$ & $12,31 \mathrm{abcde}$ \\
$\mathrm{P}_{3} \mathrm{D}_{1}$ & $14,13 \mathrm{cde}$
\end{tabular}




\begin{tabular}{|c|c|}
\hline$P_{3} D_{2}$ & 15,84 e \\
\hline$P_{3} D_{3}$ & 14,56 cde \\
\hline $\mathrm{P}_{3} \mathrm{D}_{4}$ & 13,34 abcde \\
\hline$P_{4} D_{1}$ & $15,16 \mathrm{de}$ \\
\hline$P_{4} D_{2}$ & 14,04 bcde \\
\hline $\mathrm{P}_{4} \mathrm{D}_{3}$ & 14,26 cde \\
\hline $\mathrm{P}_{4} \mathrm{D}_{4}$ & 11,78 bcde \\
\hline BNJ 5\% & 4,90 \\
\hline
\end{tabular}

Tabel 5 menunjukkan bahwa terdapat interaksi yang nyata terhadap diameter batang akibat pengaruh pemberian kompos dengan dosis yang berbeda. Perlakuan P3D2 (Kompos Kacang Tanah dengan dosis 10 ton/ha) berbeda nyata dengan perlakuan kontrol, P1D2, P1D3, P1D4, P2D2, dan P2D3, dengan nilai tertinggi yaitu $15,84 \mathrm{~mm}$.

Tabel 6. Menunjukkan pada umur 2 sampai 8 MST diameter batang terbesar diperoleh pada perlakuan P3 (kompos kacang tanah) dengan nilai sebesar berturut turut $(7,78 ; 10,42 ; 19,89 ; 20,68 ; 20,97$; dan 21,82$) \mathrm{mm}$ berbeda myata uji BNJ 5\% secara terpisah pada semua perlakuan. Perlakuan D1 (dosis kompos 5 ton/ha) adalah perlakuan tertinggi terhadap parameter diameter batang tanaman dibanding perlakuan lainnya selama pengamatan yang mempunya nilai sebesar $4,34 \mathrm{~mm} ; 6,85 \mathrm{~mm} ; 13,35$ mm; 16,07 mm; 16,36 mm; 16,36 mm; dan 16,80 mm.

Tabel 6. Rata - Rata Diameter Batang Tanaman Jagung ( $\mathrm{mm}$ ) Terhadap Pemberian Kompos Dan Dosis Yang Berbeda

\begin{tabular}{|c|c|c|c|c|c|c|}
\hline \multirow{2}{*}{ Perlakuan } & \multicolumn{6}{|c|}{ Rerata Diameter Batang (mm) Pada Umur Pengamatan (MST) } \\
\hline & 2 MST & 3 MST & 5 MST & 6 MST & 7 MST & 8 MST \\
\hline $\mathrm{P} 1$ & $3,51 \mathrm{a}$ & $5,56 \mathrm{a}$ & $14,56 \mathrm{a}$ & $14,69 \mathrm{a}$ & $14,78 \mathrm{a}$ & $15,14 \mathrm{a}$ \\
\hline P2 & $3,26 a$ & $5,66 \mathrm{a}$ & $13,62 \mathrm{a}$ & $14,42 \mathrm{a}$ & $14,47 \mathrm{a}$ & $14,69 \mathrm{a}$ \\
\hline P3 & $7,78 \mathrm{~b}$ & $10,42 \mathrm{~b}$ & $19,89 \mathrm{~b}$ & $20,68 \mathrm{~b}$ & $20,97 \mathrm{~b}$ & $21,82 \mathrm{~b}$ \\
\hline P4 & $6,34 \mathrm{a}$ & $9,05 \mathrm{a}$ & $16,86 \mathrm{a}$ & $18,33 \mathrm{a}$ & $18,66 \mathrm{a}$ & $19,69 \mathrm{a}$ \\
\hline BNJ 5\% & 3,63 & 3,77 & 4,85 & 5,23 & 5,63 & 5,41 \\
\hline D1 & 4,34 & 6,85 & 15,46 & 16,07 & 16,36 & 16,80 \\
\hline D2 & 3,87 & 6,16 & 14,61 & 15,71 & 15,95 & 16,06 \\
\hline D3 & 4,06 & 6,41 & 15,28 & 15,53 & 15,80 & 16,02 \\
\hline $\mathrm{D} 4$ & 3,62 & 6,26 & 14,98 & 15,46 & 15,36 & 15,66 \\
\hline BNJ 5\% & TN & TN & TN & TN & TN & TN \\
\hline
\end{tabular}




\section{Jumlah Daun}

Hasil analisis ragam menunjukkan perlakuan penambahan kompos jerami, kedelai, kacang tanah dan tebu pada media tanah berpengaruh nyata terhadap terhadap jumlah daun tanaman jagung pada umur tanaman 5 MST dan 8 MST hasil kemudian di uji lanjut BNJ 5\% rata-rata jumlah daun disajikan pada Tabel 4.

Pada Tabel 4 menunjukkan bahwa pada perlakuan Pemberian 4 Jenis Kompos berbeda nyata (uji lanjut BNJ 5\%) secara terpisah pada umur 3 MST 5 MST dan 8 MST. Hasil jumlah daun tertinggi terdapat pada perlakuan P3 (Kompos Kacang Tanah) dengan nilai yang berturut - turut sebesar 5,71 (helai); 9,43 dan 15,44 (helai); tetapi tidak berbeda pada semua perlakuan. Sedangkan pengaruh perlakuan faktor kedua (pemberian dosis kompos) terhadap parameter jumlah daun tidak berbeda nyata pada analisis ragam . Hasil terbaik selama pengamatan cenderung terdapat pada perlakuan D1 (dosis pupuk 5 ton/ha) dengan nilai berturut - turut 1,97 (helai); 3,50 (helai); 4,97 (helai); 5,75 (helai); 7,31 (helai); 9,08 (helai); 10,58 (helai); 13,42 (helai);

Tabel 4. Rata - Rata Jumlah Daun Tanaman Jagung (Helai) Terhadap Pemberian Kompos Dan Dosis Yang Berbeda

\begin{tabular}{ccccccccc}
\hline \multirow{2}{*}{ Perlakuan } & \multicolumn{7}{c}{ Rata - Rata Jumlah Daun (helai) Pada Umur Pengamatan (MST) } \\
\cline { 2 - 8 } & 1 MST & 2 MST & 3 MST & 4 MST & 5 MST & $\mathbf{6 ~ M S T}$ & $\mathbf{7 ~ M S T}$ & $\mathbf{8 ~ M S T}$ \\
\hline $\mathrm{P}_{1}$ & 1,86 & 3,39 & $4,61 \mathrm{a}$ & 5,67 & $6,61 \mathrm{a}$ & 8,36 & 10,47 & $11,22 \mathrm{a}$ \\
$\mathrm{P}_{2}$ & 1,92 & 3,19 & $4,47 \mathrm{a}$ & 5,31 & $6,28 \mathrm{a}$ & 8,22 & 9,75 & $10,53 \mathrm{a}$ \\
$\mathrm{P}_{3}$ & 2,00 & 3,33 & $5,71 \mathrm{~b}$ & 6,03 & $9,43 \mathrm{~b}$ & 9,56 & 11,39 & $15,44 \mathrm{~b}$ \\
$\mathrm{P}_{4}$ & 1,89 & 3,31 & $4,92 \mathrm{a}$ & 5,86 & $7,22 \mathrm{a}$ & 8,72 & 10,25 & $11,25 \mathrm{a}$ \\
\hline BNJ 5\% & TN & TN & $\mathbf{1 , 2 3}$ & TN & $\mathbf{3 , 1 3}$ & TN & TN & $\mathbf{4 , 7 7}$ \\
\hline $\mathrm{D}_{1}$ & 1,97 & 3,50 & 4,97 & 5,75 & 7,31 & 9,08 & 10,58 & 13,42 \\
$\mathrm{D}_{2}$ & 1,86 & 3,22 & 4,75 & 5,89 & 6,89 & 8,36 & 10,17 & 13,11 \\
$\mathrm{D}_{3}$ & 1,97 & 3,31 & 4,75 & 5,50 & 6,75 & 8,83 & 10,81 & 13,81 \\
$\mathrm{D}_{4}$ & 1,86 & 3,19 & 4,64 & 5,72 & 6,69 & 8,58 & 10,31 & 13,11 \\
\hline BNJ 5\% & TN & TN & TN & TN & TN & TN & TN & TN \\
\hline Keterangan: Angka yang didampingi dengan notasi yang sama pada kolom yang sama menunjukkan hasiil tidak \\
berbeda nyata dengan uji BNJ 5\%. TN = Tidak Nyata. Mst= Minggu Setelah Tanam. P1= Brangkasan \\
jerami padi, P2= Brangkasan kedelai, P3= Brangkasan kacang tanah, P4= Brangkasan tebu.
\end{tabular}

\section{Serapan N-Total Tanaman Jagung}

Hasil analisis ragam menunjukkan tidak ada interaksi yang nyata antara pemberian kompos dengan dosis yang berbeda. Tetapi secara terpisah berbeda nyata pada. Hasil analisis uji BNJ 5\% terhadap serapan N-total disajikan pada Tabel 5. 
Tabel 5. Rata-rata Serapan N-total Tanaman Jagung

\begin{tabular}{c|c}
\hline Perlakuan & Rata-rata Searapan $\mathbf{~}$-total $\mathbf{~ m g . k g} \mathbf{~}^{-1}$ \\
\hline P1 & $15653.98 \mathrm{a}$ \\
P2 & $16693.09 \mathrm{a}$ \\
P3 & $23153.94 \mathrm{a}$ \\
P4 & $26602.16 \mathrm{~b}$ \\
\hline BNJ 5\% & $\mathbf{8 1 6 0 . 6 7}$ \\
\hline D1 & $20048.12 \mathrm{a}$ \\
D2 & $22935.10 \mathrm{~b}$ \\
D3 & $21950.22 \mathrm{a}$ \\
D4 & $17169.73 \mathrm{a}$ \\
\hline BNJ 5\% & $\mathbf{8 1 6 0 . 6 7}$ \\
\hline
\end{tabular}

Keterangan: Angka yang didampingi dengan notasi yang sama pada kolom yang sama menunjukkan hasil tidak berbeda nyata dengan uji BNJ 5\%. TN = Tidak Nyata. Mst = Minggu Setelah Tanam. $\mathrm{P} 1=$ Brangkasan jerami padi, P2= Brangkasan kedelai, $\mathrm{P} 3=$ Brangkasan kacang tanah, $\mathrm{P} 4=$ Brangkasan tebu.

Berdasarkan hasil analisis uji BNJ 5\% secara terpisah, hasil tertinggi pada pemberian kompos terdapat pada perlakuan P4 dengan nilai sebesar 26602.16 mg.kg1 berbeda nyata dengan perlakuan lainnya. Sedangkan pada perlakuan dosis pupuk yang berbeda hasil tertinggi terdapat pada perlakuan D2 dengan nilai sebesar 22935.10 mb.kg-1 tidak berbeda nyata dengan perlakuan lainnya.
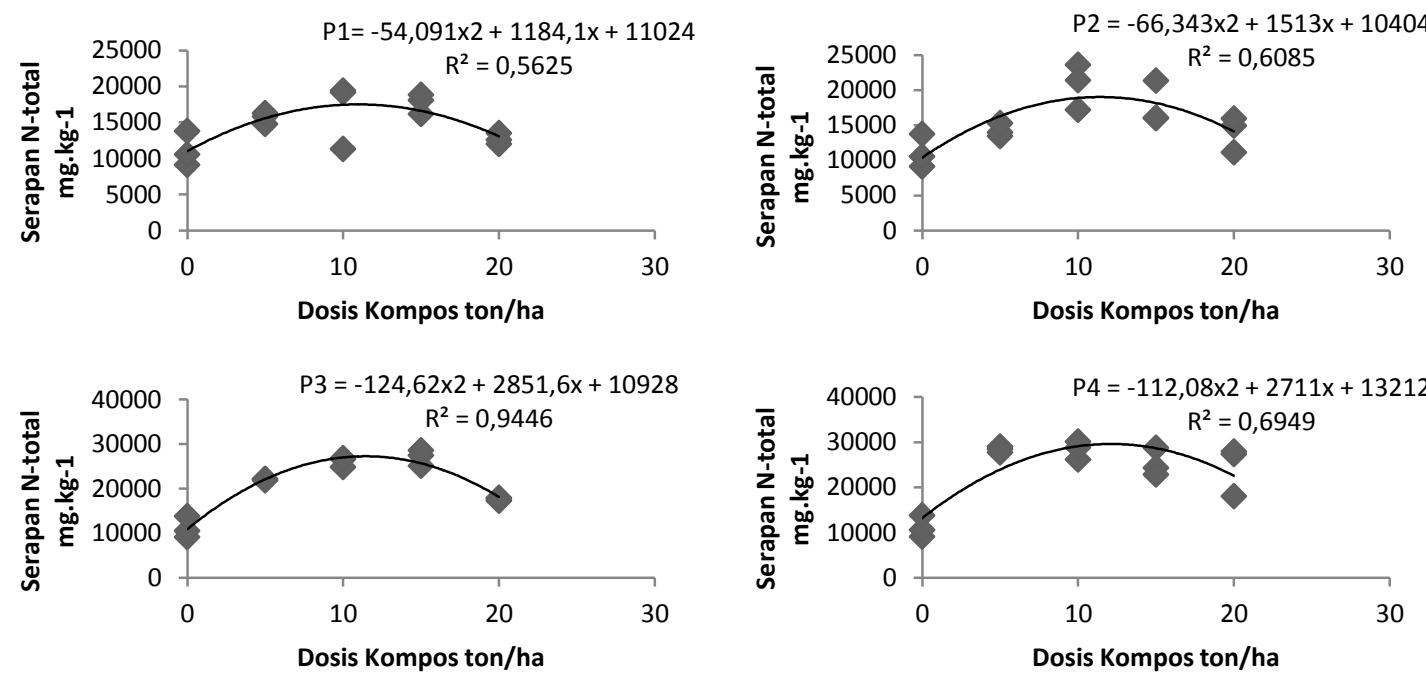

Keterangan : P1 = Jerami Padi, P2= Kedelai, P3= Kacang Tanah, P4= Tebu

Gambar 1. Grafik Hubungan Serapan N-total dengan Dosis Optimum

Berdasarkan Gambar 1 menunjukkan bahwa hubungan dosis kompos dengan serapan $\mathrm{N}$-total untuk pemberian kompos dari limbah pertanian organik kecenderungan mengikuti pola kuadratik. Artinya semakin tinggi dosis pupuk kompos hingga tingkat tertentu maka serapan $\mathrm{N}$-total menurun. Berdasarkan persamaan 
regresi (Gambar 5) P1= $-54,09 \times 2+1184,1 \times+11024$ dengan nilai determinasi (tingkat pengaruh dosis kompos terhadap serapan $\mathrm{N}$-total) sebesar $56,25 \%$ diperoleh dosis optimum 10,94 ton/ha, $P 2=-66,34 x 2+15,13 x+10404$ dengan nilai determinasi (tingkat pengaruh dosis kompos terhadap serapan $\mathrm{N}$-total 60,85\% diperoleh dosis optimum 11,40 ton/ha, P3=-124,62 x2 + 2851,6 x + 10928 dengan nilai determinasi (tingkat pengaruh dosis kompos terhadap serapan $\mathrm{N}$-total) sebesar $94,46 \%$ diperoleh dosis optimum 11,44 ton/ha , $\mathrm{P} 4=-112,08 \times 2+2711 \mathrm{x}+1312$ dengan nilai determinasi (tingkat pengaruh dosis kompos terhadap serapan $\mathrm{N}$-total) sebesar $69,49 \%$ diperoleh dosis optimum 12,09 ton/ha

\section{Pengaruh Pemberian Kompos dengan Pemberian Dosis yang Berbeda Terhadap Pertumbuhan Tanaman Jagung (Zea mays)}

Hasil analisis ragam menunjukkan terdapat pengaruh yang nyata akibat pemberian 4 macam kompos dengan tingkat dosis yang berbeda terhadap variabel pertumbuhan tanaman jagung meliputi tinggi tanaman, namun tidak ada interaksi yang nyata pada umur tanaman jagung $1,3,4,5,6$, dan 7 kecuali pada 8 MST. Pada variabel pertumbuhan diamter batang, jumlah daun dan luas daun tanaman jagung umur 2-8 MST tidak ada interaksi dan antar perlakuan tidak berpengaruh nyata pada uji BNJ 5\%, perlakuan P3 (kompos kacang tanah) cenderung memiliki pengaruh yang lebih baik terhadap pertumbuhan tanaman jagung variabel pertumbuhan diamter batang, jumlah daun dan luas daun tanaman jagung umur 2-8 MST dibandingkan dengan semua perlakuan. Hal ini disebabkan karena P3 (kompos kacang tanah) merupakan bahan organik yang berkuliatas baik yang memiliki kandungan $\mathrm{N}$ yang tinggi, serta kandungan lignin, selulosa, polifenol dan $\mathrm{C} / \mathrm{N}$ ratio yang lebih rendah. $\mathrm{N}$ total yang dimiliki kompos kacang tanah menyebabkan unsur hara yang terkandung dalam kompos lebih cepat diserap oleh tanaman, karena kompos kacang tanah mengalami dekomposisi dengan cepat didalam tanah lebih cepat. Unsur $\mathrm{N}$ merupakan unsur makro yang sangat dibutuhkan oleh tanaman dan dibutuhkan dalam jumlah banyak selama proses pertumbuhan tanaman. Sholihah et al., (2002), mengemukakan bahwa laju mineralisasi berkorelasi dengan nisbah $\mathrm{C} / \mathrm{N}$ rasio. Tanaman yang cukup mendapat suplai $\mathrm{N}$ akan membentuk helai daun yang luas dengan kandungan klorofil yang tinggi. Sehingga tanaman dapat menghasilkan asimilat dalam jumlah cukup untuk menopang pertumbuhan vegetatif (Wijaya, 2008). Menurut Sudartiningsih, Utami dan Prasetya (2002), Nitrogen merupakan penyusun dari semua protein dan asam nukleat. Sedangkan pengaruh dosis terbaik terhadap parameter pertumbuhan (tinggi tanaman, diameter batang, jumlah daun dan luas daun) tanaman jagung adalah perlakuan D1 
(dosis 5 ton/ha) selama pengamatan. Dari hasil analisis ragam tersebut terlihat bahwa pemberian dosis kompos tidak berpengaruh nyata terhadap variabel pengamatan. hal ini diduga pengaruh lingkungan mendominasi dalam kelangsungan pertumbuhan tanaman jagung. Dimana kondisi di dalam lingkungan hidup tanaman jagung tepatnya di rumah plastik terdapat pengaruh penurunan intensitas cahaya matahari sehingga mengakibatkan gejala etiolasi atau pertumbuhan tanaman memanjang dari tanaman. hal ini dapat diartikan bahwa dengan kondisi lingkungan tersebut tanaman jagung memiliki aktivitas pembentukan auksin yang lebih aktif sehingga dapat mendorong pertumbuhan tinggi tanaman.

\section{Pengaruh Pemberian Kompos dengan Dosis Yang Berbeda Terhadap Serapan N-total}

Hasil pengamatan dan analisis pada parameter pengamatan Serapan $\mathrm{N}$ tajuk dan akar, N-total, yang terbaik cenderung terdapat pada perlakuan P4D1 dengan nilai sebesar 26344,35 (mg.Kg-1), walaupun tidak sesuai yang diharapkan karena kompos tebu memiliki $\mathrm{C} / \mathrm{N}$ rasio yang lebih tinggi dibandingkan dengan perlakuan lainnya (Lampiran 1: hasil analisis dasar kompos) semakin tinggi nilai $\mathrm{C} / \mathrm{N}$ rasio maka semakin rendah pula kandungan $\mathrm{N}$ tetapi hasil dari P4D1 tidak berbeda nyata dengan perlakuan P3D1 (kompos kacang tanah dengan dosis 5 ton/ha), P3D2 (kompos kacang tanah dengan dosis 10 ton/ha), P3D3 (kompos kacang tanah dengan dosis 15 ton/ha), artinya pemberian kompos kacang tanah dan tebu dengan dosis 5 ton/ha 10 ton/ha 15 ton/ha memberikan hasil yang sama. Tingginya serapan $N$ pada perlakuan P4D1 (kompos tebu dengan dosis5 ton/ha) disebabkan karena pengaruh dari pemberian pupuk dasar urea dengan dosis 0,375 gram/pot sehingga kemungkinan besar tanaman lebih banyak menyerap $\mathrm{N}$ yang berasal dari pupuk dasar tersebut dan sisa-sisa $\mathrm{N}$ di dalam tanah selain itu berkembangnya sistem perakaran pada perlakuan P4D1 sangat mendukung serapan $\mathrm{N}$ yang maksimal. Besarnya nilai serapan $\mathrm{N}$ mempengaruhi peningkatan pertumbuhan tanaman jagung dimana, pada fase vegetatif tanaman secara aktif menyerap unsur hara $\mathrm{N}$ dalam bentuk ion nitrat NO3- dan ion ammonium $(\mathrm{NH} 4+)$ baik yang telah tersedia di tanah maupun dari pupuk. Nitrogen yang diserap kemudian diubah dalam bentuk asam nukleat dan asam amino untuk biosintesis protein dan pertumbuhan baik vegetatif maupun generatif (Larcher 1995). Terserapnya $\mathrm{N}$ oleh tanaman dipengaruhi beberapa faktor internal, seperti kondisi fisiologi tanaman, jenis tanaman dan kebutuhan tanaman pada hara tertentu. Faktor eksternal atau lingkungan yang mempengaruhi terserapnya $\mathrm{N}$ oleh tanaman, yaitu cahaya, udara, air 
dan $\mathrm{pH}$ tanah (FAPRC 1995). Nitrogen pada tanaman berfungsi dalam memperluas area daun sehingga dapat meningkatkan fotosintesis (Chaturvedi 2005).

Interaksi antara perlakuan pemberian 4 macam kompos (kompos jerami, kompos kedelai, kompos kacang tanah dan kompos tebu) dengan tingkat dosis yang berbeda tidak berpengaruh nyata $(P>0,05)$ terhadap $N$ recovery. Pemberian kompos tebu dengan dosis 5 ton/ha tidak dapat memperkecil resiko kehilangan $\mathrm{N}$ akibat pencucian atau penguapan. Berbeda lain dengan perlakuan P3D4 (kombinasi kompos kacang tanah dengan dosis 20 ton/ha) mempunyai nilai efisiensi yang tinggi dibanding perlakuan lainnya dengan nilai sebesar 27,39\% dapat diartikan bahwa pemberian kompos kacang tanah dengan dosis 20 ton/ha mampu menekan resiko kehilangan $\mathrm{N}$ akibat pencucian dan kehilangan $\mathrm{N}$, namun $\mathrm{N}$ yang diserap tanaman jagung rendah karena lebih dominan dipengaruhi oleh faktor lain, dimungkinkan perlakuan P3D4 ini pengomposan masih kurang matang akibatnya $\mathrm{N}$ yang tersedia untuk tanaman sedikit sehingga $\mathrm{N}$ yang diserap oleh tanaman juga rendah.

\section{Kesimpulan dan Saran}

\section{Kesimpulan}

Berdasarkan hasil penelitian dapat disimpulkan bahwa,

1. Tidak ada interaksi yang nyata pada parameter variabel pengamatan tinggi tanaman, diameter batang dan jumlah daun akibat pemberian 4 jenis kompos (jerami padi, kedelai, kacang tanah, dan tebu) dengan kombinasi dosis ( 5 ton/ha, 10 ton/ha, 15 ton/ha, dan 20 ton/ha) selama pengamatan kecuali pada parameter tinggi tanaman umur 8 MST.

2. Perlakuan P3 (kacang tanah) dan D1 (dosis 5 ton/ha) mampu meningkatkan pertumbuhan tanaman jagung, sedangkan perlakuan P4 dan D2 mampu meningkatkan serapan $\mathrm{N}$-total.

\section{Saran}

Untuk Mendapatkan Pertumbuhan dan Serapan N disarankan menggunakan Kompos dari Kacang Tanah dengan Dosis sekitar 11,21 11,44 ton/ha. Untuk aplikasi kompos tebu jerami dan kedelai sebaiknya dikomposkan ulang dengan waktu yang lama lagi sebelum digunakan. Perlu dilakukan penelitian lanjutan untuk dapat mengetahui hasil produksi akibat pemberian kompos dengan dosis yang berbeda

\section{Ucapan Terima Kasih}


Peneliti mengucapkan terima kasih kepada PT Indofood Sukses Makmur, Tbk. yang telah memberi dana penelitian melalui program Indofood Riset Nugraha 2019/2020 dari awal hingga akhir penelitian dilaksanakan.

\section{DAFTAR PUSTAKA}

Becker, M., J. K. Ladha, I. C. Simpson, and J. C. G. Ottow. 1994. Parameters affecting the nitrogen mineralization of plant residues in flooded soils. Soil Sci. Soc. Am. J. 58: 1666-1671

Clain Jones and Jeff Jacobsen. 2005. Nitrogen cycling, testing and fertilizer recommendations. Nutrient Management. Montana State University.

Frankenberger W.T. and H.M. Abdelmagid. 1985. Kinetic Parameter Of Nitrogen Mineralization Rates Of Leguminosae Crops Intercorporated Into Soil. Plant and Soils 87.

Havlin, J.L., J.D. Beaton, S.L. Tisdale, and W.L. Nelson. 1999. Soil Fertility and Fertilizers, 6th ed. Prentice Hall, New Jersey. 501p.

Handayanto, E . 2000. Stimulasi dan Retardasi Mineralisasi Nitrogen akibat penambahan bahan organik baru. Kalimantan. Agrikultura. 7: 14-23.

Handayanto, E. and Sholihah, A. 2010. Nitrogen mineralization by maize from previously added legume residues following addition of new legume residues using 15N labelling technique. Journal of Tropical Agriculture 48 (1-2), 23-27.

Handayanto, E., Cadisch, G. and Giler, K.E. 1994. Nitrogen release from prunings of legume hedgerow trees in relation to quality of the prunings and incubation methods. Plant and Soils 160, 237-248.

Handayanto, E., Cadisch, G. and Giller, K.E. 1995. Manipulation of quality and mineralization of tropical legume tree prunings by varying nitrogen supply. Plant and Soils 176, 149-160.

Havlin, J.L., J.D. Beaton, S.L. Tisdale, and W.L. Nelson. 1999. Soil Fertility and Fertilizers, 6th ed. Prentice Hall, New Jersey. 501p.

Indriyati, L.T, Supiandi S, Latifah K.K, Rykson S, Sudarsono, dan Widjang H.S. 2007. Transformasi Nitrogen dalam Tanah Tergenang: Aplikasi Jerami Padi dan Kompos Jerami Padi. J. Tanah Trop. 13 (3): 189-197.

Kang, B.T, and Mulongoy,K, 1992. Nitrogen Contribution Of Woody Legume In Alley Cropping System. In Biological Nitrogen Fixation and Sustainability Of tropical Agriculture. Eds.K.Mulongoy, M.Gueye, and D.S.C.Spenser. John Wiley \& Sons, Chichester,UK. USA

Mafongoya,P. L, P. K. R. Nair and B. H. Dzowela. 1997. Mineralization Of Nitrogen from Decomposing Leaves of Multipurpose Trees as Affected by Their Chemical Composition. Biol Fertil Soils.27 :143-148. 
Mambo. 2011. Peningkatan Produksi \& Kualitas CPO Kelapa Sawit dengan Teknologi Biotama.http://www.biotama.com/index.php?option=comcontent\&task=view\&id= 80\&Itemid $=1$

Reeves JB. 1993. Chemical studies on the composition of fibre fractions and lignin determinations. J Dairy Sci $76: 120-128$.

Sholihah, A. dan S., Muslikah. 2006. Pemilihan Tanaman Berkualitas sebagai Pengganti Pupuk Nitrogen Pada Pertumbuhan dan Produksi Tanaman Jagung. Laporan Penelitian Dosen Muda.

Sumarsih, S. 2010. Peranan Mikroba dalam Perubahan Senyawa Nitrogen. Fakultas Pertanian UPN "Veteran" Yogyakarta.

Swift MJ, Heal OW, Anderson JM. 1979. Decomposition in terrestrial. ecosystems. Studies in Ecology, vol. 5. University of California Press, Berkeley, Calif. 